\title{
Supply-Chain Culture Clashes in Europe. Pitfalls in Japanese Service Operations
}

\author{
M.B.M. de Koster and M. Shinohara
}

\begin{tabular}{|l|l|}
\hline \multicolumn{2}{|l|}{ ERIM REPORT SERIES RESEARCH IN MANAGEMENT } \\
\hline ERIM Report Series reference number & ERS-2006-007-LIS \\
\hline Publication & January 2006 \\
\hline Number of pages & 18 \\
\hline Persistent paper URL & \\
\hline Email address corresponding author & rkoster@rsm.nl \\
\hline Address & Erasmus Research Institute of Management (ERIM) \\
& RSM Erasmus University / Erasmus School of Economics \\
& Erasmus Universiteit Rotterdam \\
& P.O.Box 1738 \\
& 3000 DR Rotterdam, The Netherlands \\
& Phone: $\quad+31104081182$ \\
& Fax: $\quad+31104089640$ \\
& Email: info@erim.eur.nl \\
& Internet: $\quad$ www.erim.eur.nl \\
\hline
\end{tabular}

Bibliographic data and classifications of all the ERIM reports are also available on the ERIM website: www.erim.eur.nl 


\section{ERASMUS RESEARCH INSTITUTE OF MANAGEMENT}

\section{REPORT SERIES}

\section{RESEARCH IN MANAGEMENT}

\begin{tabular}{|c|c|}
\hline \multicolumn{2}{|c|}{ ABSTRACT AND KEYWORDS } \\
\hline Abstract & $\begin{array}{l}\text { Japanese companies value service and quality highly and they put much effort in realising this. } \\
\text { However, survey research carried out in } 2001 \text { among senior managers of Japanese logistics } \\
\text { companies in the Netherlands, indicated that these efforts do not result in significant } \\
\text { performance differences compared to western companies. In this exploratory paper, we report of } \\
\text { company visits and interviews with managers of Japanese logistics companies in Western } \\
\text { Europe. They described a clash of cultures underlying their operations, prohibiting them from } \\
\text { achieving performance excellence. The causes focus around two key factors: the unique } \\
\text { concept of Japanese service, based on future rewards which are absent in Western Europe; } \\
\text { different employment circumstances in Western Europe, which make Japanese human resource } \\
\text { management ineffective, and the Japanese career development system which makes that } \\
\text { Japanese managers do not always have the right focus in their job abroad. We conclude that } \\
\text { Japanese subsidiaries in Western Europe should keep on nourishing their unequalled service } \\
\text { standards, while simultaneously adapting to efficiency standards of Western business practices } \\
\text { in order to become more successful in the future. }\end{array}$ \\
\hline Free Keywords & Logistics, Service Operation, Quality, Japanese Culture, Europe \\
\hline Availability & $\begin{array}{l}\text { The ERIM Report Series is distributed through the following platforms: } \\
\text { Academic Repository at Erasmus University (DEAR), DEAR ERIM Series Portal } \\
\text { Social Science Research Network (SSRN), SSRN ERIM Series Webpage } \\
\text { Research Papers in Economics (REPEC), REPEC ERIM Series Webpage }\end{array}$ \\
\hline Classifications & $\begin{array}{l}\text { The electronic versions of the papers in the ERIM report Series contain bibliographic metadata } \\
\text { by the following classification systems: } \\
\text { Library of Congress Classification, (LCC) LCC Webpage } \\
\text { Journal of Economic Literature, (JEL), JEL Webpage } \\
\text { ACM Computing Classification System CCS Webpage } \\
\text { Inspec Classification scheme (ICS), ICS Webpage }\end{array}$ \\
\hline
\end{tabular}


Supply-chain culture clashes in Europe. Pitfalls in Japanese service operations

\author{
M.B.M. de Koster ${ }^{1}$, M. Shinohara ${ }^{2}$ \\ ${ }^{1}$ RSM Erasmus University, PO Box 1738, 3000 DR Rotterdam, the Netherlands, rkoster@rsm.nl \\ ${ }^{2}$ School of Marine Science \& Technology, Tokai University, 3-20-1 Shimizu-ku Orido, Shizuoka \\ 424-8610, Japan, shinoma@scc.u-tokai.ac.jp
}




\title{
Supply-chain culture clashes in Europe. Pitfalls in Japanese service operations
}

\begin{abstract}
Japanese companies value service and quality highly and they put much effort in realising this. However, survey research carried out in 2001 among senior managers of Japanese logistics companies in the Netherlands, indicated that these efforts do not result in significant performance differences compared to western companies. In this exploratory paper, we report of company visits and interviews with managers of Japanese logistics companies in Western Europe. They described a clash of cultures underlying their operations, prohibiting them from achieving performance excellence. The causes focus around two key factors: the unique concept of Japanese service, based on future rewards which are absent in Western Europe; different employment circumstances in Western Europe, which make Japanese human resource management ineffective, and the Japanese career development system which makes that Japanese managers do not always have the right focus in their job abroad. We conclude that Japanese subsidiaries in Western Europe should keep on nourishing their unequalled service standards, while simultaneously adapting to efficiency standards of Western business practices in order to become more successful in the future.
\end{abstract}

\section{Introduction.}

Since the late 70s, Western companies have adopted total quality management (TQM) and JIT procurement and production methods from their Japanese counterparts. Japanese lean manufacturing techniques, particularly in the automotive industry, astonished Western manufacturers by realising shorter throughput times, inventory levels, shorter cycle times, but also by the much higher quality of the products (Schonberger, 1982). One of the most remarkable Japanese "implants" is the NUMMI plant described in many textbooks (f.e. Slack et al, 2001), which became GM's best performing US plant within a few years after installing a Japanese management team. Since then, their world-class manufacturing practices quickly became the new quality standard for the U.S. and European automotive industry (Liker and Wu, 2000). The great emphasis and achievements of Japanese firms in the areas of service and quality often strike Western Europeans as remarkable. Timely delivery in Japan means 100\% of deliveries precisely on time. High quality means zero defects. Many authors attribute the successes of Japanese operations to the much larger management focus on operations and quality practices compared to Western companies (Adler and Cole, 1993; Van Breukelen et al. 1998; Lin et al, 2004).

On the other hand, however, the emphasis on quality may sacrifice productivity. Japanese quality and service orientation need time and human resources and are not always cost-efficient (Fahy and Taguchi, 1995). In a recent survey research among European distribution centres, De Koster and Warffemius (2005) showed that, although great effort was taken to meet the Japanese productivity and quality standards, performance differences (measured by error-free deliveries 
and worker productivity) from the Western counterparts were not significant.

Our research questions are, therefore, what challenges Japanese logistics management faces in Europe, whether the emphasis on quality and service pays off sufficiently and, if this is not the case, what suggestions can be made to improve the situation. As a survey is not likely to reveal the real causes for underlying factors, we opted to go for an exploratory multiple-case study on Japanese-owned logistics firms. According to Meredith (1998), the case method is particularly fit to answer the questions of why, what and how, with a relatively full understanding of the nature and complexity of the complete phenomenon. Furthermore, it lends itself to early, exploratory investigations where the variables are still unknown and the phenomenon not at all understood. As the questions contained issues sensitive to the firms investigated, we decided to go for semi-structured interviews (partly in Japanese) in an open atmosphere with ample opportunity for the interviewees to speak up. We selected and visited 23 Japanese-owned logistics companies (for an overview, see the Appendix) from different sectors, with different supply-chain positions (manufacturers, distributors, and service providers).

In the next section we first describe differences in human resource management practices between Japanese and Western firms. In section 3 we report on the problems Japanese logistics firms in Western Europe face, and give a number of examples illustrating the difficulties in achieving Japanese quality and service levels. In section 4 we look for the main underlying causes of these problems. We finish with a discussion about ways to overcome the problems and draw conclusions.

\section{Are Japanese companies different?}

Several authors claim that quality management practices have direct impact on organisational performance. Madu et al. (1995) found a causal relation between a quality construct (i.e. customer satisfaction, employee satisfaction, employee service quality) and organisational performance. Forza en Filippini (1998) found that TQM (total quality management) improved quality conformance and customer satisfaction. Samson and Terziovslei (1999) found a significant relation between TQM practice and organisational performance. Although not all authors include the same dimensions to measure the quality management practice construct, dimensions typically include: training, product/service design, supplier quality management, (attention for) process management and improvement, quality data and reporting, and benchmarking.

Emphasis on quality management practices is however not sufficient for company success. The results of an empirical study by Powell (1995) showed that "most features generally associated 
with Total Quality Management - such as quality training, process improvement and benchmarking - do not generally produce advantage, but that certain tacit, behavioural, imperfectly imitable features - such as open culture, employee empowerment, and executive commitment - can produce advantage”. In other words, employee relationship practices may also play a role. On top of this, many authors include customer (service) orientation as one of the dimensions of quality management practices (Powell, 1995, Lin et al., 2004).

The above literature therefore suggests a causal model as sketched in Figure 1. We included customer orientation as a construct separate from quality management practices.

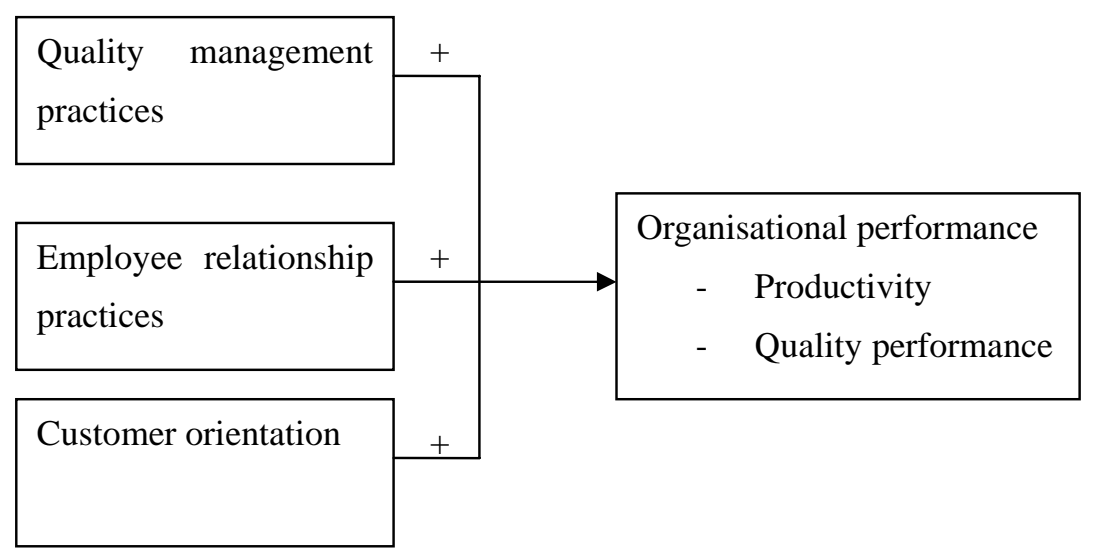

Figure 1. Quality management and employee relationship practices and customer orientation drive organisational performance.

As mentioned in the introduction, Japanese companies are known for their quality management practices and customer service orientation. Several authors also found that Japanese companies have more attention for employee relationship practices than Western companies, which have their roots in cultural differences. Ouchi and Jaeger (1978) make a distinction between typical American companies and typical Japanese companies, which they denote by type-A and type-J organisations. According to these authors, Japanese companies in the USA have adapted to circumstances and, ideally, exhibit a type- $\mathrm{Z}$ organisation, which is a hybrid adaptation of type $\mathrm{J}$ and type A. Their organisational types are shown in Figure 2.

\begin{tabular}{|l|l|l|}
\hline Type A (American) & Type J (Japanese) & Type Z (modified American) \\
\hline Short-term employment & Lifetime employment & Long-term employment \\
\hline Individual decision-making & Consensual decision-making & Consensual decision-making \\
\hline Individual responsibility & Collective responsibility & Individual responsibility \\
\hline Rapid evaluation and & Slow evaluation and promotion & Slow evaluation and promotion \\
\hline
\end{tabular}




\begin{tabular}{|l|l|l|}
\hline promotion & & \\
\hline Explicit, formalised control & Implicit, informal control & $\begin{array}{l}\text { Implicit, informal control with } \\
\text { explicit, formalised measures }\end{array}$ \\
\hline Specialised career path & Non-specialised career path & $\begin{array}{l}\text { Moderately specialised career } \\
\text { path }\end{array}$ \\
\hline Segmented concern & Holistic concern & $\begin{array}{l}\text { Holistic concern, including } \\
\text { family }\end{array}$ \\
\hline
\end{tabular}

Figure 2. Differences between Japanese-owned and American companies in the USA (Ouchi and Jaeger, 1978)

The dimensions quality performance and productivity of the dependent construct Organisational performance are not fully independent. If much effort is put in Quality management practices, this may lead to better Quality performance, but possibly at the cost of a reduced efficiency. Indeed, Yeung et al. (2004) state that not all dimensions of the three independent constructs contribute equally to the Organisational performance dimensions. Process improvement (part of quality management practices) primarily affects cost-related performance (productivity), while customer-oriented practices lead directly to customer satisfaction (closely related to quality of the service). Organisational performance therefore, is a matter of striking the right balance between inputs and outputs. Hence, it is not obvious that Japanese companies, albeit the effort put in quality management practices, employee relationships, and customer orientation strike a better overall balance. In a study of 136 companies in Taiwan, Lin et al. (2004) investigated differences in quality management practices, employee relationship, and customers' relations and found that Japanese-owned firms exhibit significantly higher efficiency performance (measured by the ratio of productivity, competitiveness, and financial outputs over various inputs related to the independent constructs of Figure 1) than American or Taiwanese-owned firms. This implies that Japanese firms would be better able to strike this balance than the American- or Taiwanese-owned firms. Simultaneously, however, Lin et al. (2004) remark that "there is a large input excess in employees' relations for Japanese-owned firms” for their sample of companies in Taiwan, implying that emphasis on employee relations do not sufficiently pay off in efficiency performance. This is in line with findings of De Koster and Warffemius (2005), who carried out a survey among 65 logistics managers of European distribution centres (EDC), of which 12 American and 14 Japanese that were not outsourced. Focus of the survey was on finding potential performance differences (in productivity, quality, and flexibility) between American and Japanese distribution centres and between 3PL operations and own-account facilities. From this survey, differences showed up in the way Japanese and Western managers organise their operations. Japanese facilities have significantly $(p=0.04)$ more middle- and top-managers from the home country than American operations, where local management dominates (see Figure 3). Also, 
Japanese firms tend to employ more quality management methods, with particularly significant differences for the use of quality circles and kaizen (continuous improvement practices). However, no significant difference in the quality realised (measured by the percentage of order errors) and no significant difference in productivity with American-owned firms could be measured. On the contrary, the European-owned firms appeared to be close to more flexible $(p=0.08)$ than Japanese or American-owned firms. Although these results were somewhat unexpected, it matched with the experience of Japanese managers in Europe struggling to balance between service orientation and efficiency.

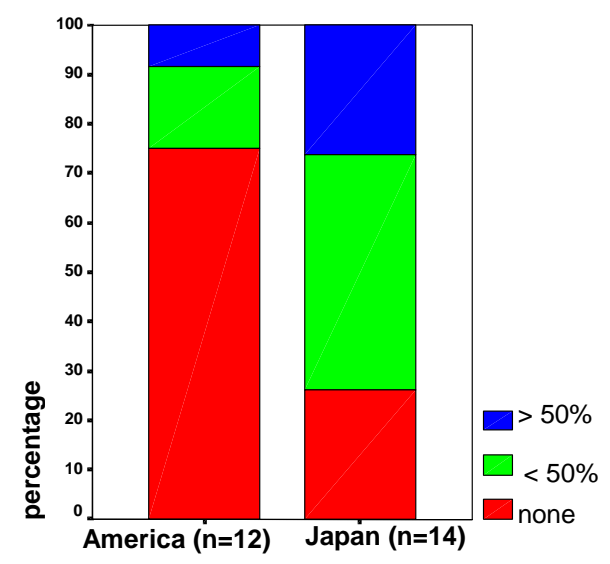

Figure 3. Percentage middle- and top-managers from the home country in the own-account EDCs.

\section{Interview results}

The main objectives of the interviews were to establish validity of the lack of performance excellence and causes for this. In view of the sensitivity of the subject the interviews were held in an open atmosphere, with ample opportunity for the managers to speak up. People and company names have been changed in this paper and we chose to present findings in a rather descriptive manner. Interviews focused on customer service, quality management, process management and human resource management practices. Interviews were held with both Japanese (often the director or CEO) and European logistics staff (for example the warehouse manager) in separate meetings. While talking with these managers, many of them expressed their frustration with the way their organisation was run. From the interviews five main problem areas emerged for Japanese logistics operations in Western Europe, each of which was applicable to a majority of the firms. 
- A frustrating decision-making process

- Japanese managers have difficulty to maintain a Japanese way of management

- Differences of objectives between the firm and the individual Japanese managers

- Customer service and quality orientation, without clear pay-off

- Balancing between arms-length relationship and networking

In the sequel we describe these problems and illustrate them with some examples revealed to us.

\section{a. A frustrating decision-making process}

A majority of the interviewed non-Japanese staff working for Japanese companies in Europe complained about the slow decision-making by the management. If European management makes a proposal, at first they do not receive any response from their Japanese boss. This is attributable to the Japanese business culture to carry out a thorough investigation of the matter and its background. This is always required before drawing up a proposal, which is normally done by the junior staff. Managers of multiple levels at the head office in Japan are required to examine and make necessary corrections to the proposal. The role of the management of the European subsidiary in the decision-making may be, therefore, only to present a proposal to the head office. However, once a formal decision has been made actions are taken quickly and collectively. At that stage, no objection or hesitation is allowed any more, since all the people involved in the project, from the bottom to the top, have already been offered a chance to express their opinions and change the direction of the decision. Proposals for building warehouses and office buildings at MOL and Yamaha took a similar cumbersome process for analysis and decision- making, but the implementation was expeditious after the decision had been made.

In the Western business culture, discussions are important to come to a decision. Therefore, in Europe, a decision is supposed to take place after the discussions, whereas in the Japanese environment, oral communication is not regarded as an important method of exchanging opinions (Nakane, 1967). Only by written documents, the matter can be examined precisely. The Japanese linguistic characteristics to use vague expressions in conversations seem to have led to this business tradition (Oe, 1995). This decision-making process is widely known as "Ringi System", or proposal circulation system. Example 1 illustrates this decision making process.

\section{Example 1. Bottom-up decision-making}

The CEO of a Japanese firm's European logistics service subsidiary has to decide on employment, remunerations, promotions, organisations, finance, warehouse space, and truck leasing, which 
would fall under the discretion of the local management at non-Japanese firms. For such decisions the CEO must write a proposal to the division head at the head quarter in Japan supervising the European subsidiary. The next step is unique. The proposal is normally not discussed between the European CEO and the division head in Japan, but is first examined by the junior staff of both organisations. After they have completed examination, the manager at the head quarter reads both the proposal and the examination report, and makes amendments again. Then, it will be examined by the deputy general manager and, then, by the general manager of the division for a decision. An important decision sequentially goes further up to higher-ranked persons or the board meeting. In the examination process from the junior level and up to the top step-by-step upwards, those managers frequently ask questions to the European CEO and his subordinates. This process is important to make the proposal a perfect document covering all the necessary supporting data, reasoning, competition, effect on the market, and estimated profit for the next several years, and makes it sometimes look almost "risk-free".

A process as described in Example 1 is customary for large Japanese firms. In this way, decision-making is documented, and the people fully support the project and cooperate in the implementation. However, according to the European staff we interviewed, the Japanese director in Europe tends to follow a similar decision-making process for minor matters as well. If a non-Japanese manager of the European subsidiary is involved somewhere in such a process, he will often be frustrated to see the bureaucracy and the tardy process, which may sometimes yield negative responses without clear explanations by the Japanese manager. Japanese firms delegate less power to the head of an overseas subsidiary than American or European companies would do.

\section{b. Japanese managers have difficulty to maintain Japanese way of management}

'Genba', or shop floor, attention of Japanese management is considered as one of the most important elements of competence.

Mr. Maeda, former managing director of Washin BV, the subsidiary of a Japanese company, says, "When I arrived in the Netherlands as newly appointed managing director of the company, I woke up early in the morning one day and went to my company at 6 am to shake hands with all the sixty truck drivers and see them off departing for the day's business. This was done in order to show my commitment to them and co-working spirit.” Mr. Teranishi, general manager at the Rotterdam branch of Japan Logistics BV, keeps his second desk in the large room together with his operational staff to oversee daily practices and track what is going on in his business sphere everyday. He rarely uses his private room. Listening to the business conversations of the staff is deemed important to perform his duty as the top manager. This is similar to the situation in Japan, where the general manager and section managers share an office with all their staff. 
We found that, at many Japanese logistics companies in Europe, high-ranked Japanese managers tend to be concerned about daily operations. Reports on important operational matters must reach the top management without fail or delay. Accidents and damages to the goods are matters of utmost concern to them. In case of an incident with a Japanese client's goods during storage or transport, the senior manager of the Japanese logistics service provider would immediately pay a visit to this client for apology. This can create a rather awkward feeling among non-Japanese staff of the Japanese firm. While Japanese managers are committed to operational excellence and are extremely nervous about mistakes, the non-Japanese staffs accept that humans can make mistakes. What disconcerts non-Japanese staff is that Japanese managers often take severe disciplinary measures on the person who has made a mistake or damaged the goods.

Japanese managers try to train non-Japanese staff how to react to an angry Japanese customer in case of trouble. It is not allowed to argue with the customer even if the customer caused the problem. "Apologise first, and speak reason later" is an established method to keep long-term relationships with clients. Japanese service providers are pressed by their (Japanese) customers to yield a Japanese service style. Trying to adapt the local personnel to this business culture often leads to discord between the Japanese and the European staff.

\section{c. Personal aims versus business objectives}

Many of the Japanese we met declared their will to continue to work for the same company until retirement; the overseas assignment is a temporary status in the chain of a long career within the same company. Apparently, Japanese managers rate a position in the core business at the head quarter higher than a position at a local office, even if it is one rank higher. They can take the overseas assignment as an opportunity for broadening the experience, a chance to show entrepreneurial ability, an anxious period of future uncertainty away from the important senior bosses in Japan, or a nice time to enjoy European culture and tourism. If they regard the European position interim, the local business will lose growth potential.

In many Japanese companies, the appointment of a manager to an overseas subsidiary is not determined by the competency of the person to manage the company in a multicultural setting, but as a result of a large-scale regular staff reshuffling. According to the survey by The Japan Institute of Labour (1999), only 57\% of the Japanese managers seconded to Europe desired this prior to the secondment, $14 \%$ of them were reluctant to go to Europe, and $34 \%$ did not have any specific aspiration about the place of work. The wish of the spouse is usually not at all taken into consideration. According to the survey results, Japanese managers abroad worry about the education of their children (42\%), housing and saving for the future (37\%), and feel to be left behind in the company politics while being away from the head office (23\%). 
Accordingly, many Japanese managers working at European subsidiaries have difficulty to innovate the European business. Losing an important Japanese customer in Europe badly affects the evaluation at the head office. Therefore, keeping Japanese customers supersedes an ambition to acquire a new European customer. See also Example 2.

\section{Example 2. Logistics service providers: European or Japanese customers?}

Mainichi Logistics Ltd., a Japanese logistics service provider, took over a well-known Dutch competitor to extend its European business. Part of the senior Dutch management was replaced with a Japanese one. However, a large part of employees were still Dutch due to the parent's policy of management localisation. The goal was to integrate the Dutch firm into the global strategy of the Japanese parent by merging Japanese quality standards with Dutch rationality. When the Japanese managers were assigned to the Dutch firm, they were bewildered with the directness of the Dutch staff and the lack of their dedication to customer service. On the other hand, the Dutch staff claimed that the European customers showed bewilderment in the different manners and ways of communication of the Japanese managers. Japanese managers often only pay courtesy calls at the European customers and make few commitments until they have obtained an approval of the head office in Japan. The Dutch managers were asked to adapt themselves to the Japanese way of service for the Japanese customers and maintain their European style for the European customers. After some years, the Dutch managers realised that the Japanese managers and their bosses in Japan were only interested in the existing Japanese clients.

\section{d. Service orientation, without clear pay-off}

Japanese dedication to customer service is sometimes overwhelming. Many customers are treated indulgently by their suppliers and logistics service providers. Therefore, almost all the Japanese logistics service providers interviewed complained about the overly demanding and unreasonable attitude of their Japanese customers. They need a special relationship management, which has been cultivated in the long history of business interactions. Therefore, Japanese managers are reluctant to leave those matters to the European managers. (See Example 3.)

\section{Example 3. Import of European wine in Japan}

A large Japanese wine importer buys French and German wines and ships them in full container loads to Japan. Stock is kept in a European warehouse, operated by a Japanese logistics service provider. When the wine cartons arrive in this warehouse, warehouse workers apply a small label 
to each bottle, showing the Japanese description of the product, country of origin, importer's name etc., as required by the Food Hygiene Act of Japan. The importer also requests the warehouse to make a sample check of the bottles: labelling, transparency of the content, and the cleanliness of corks. Bottles are excluded from the shipment if the label is not evenly adhered, sediment is found, or the cork is found moulded, because the Japanese distributors will instantly reject those goods. Unfortunately for the importer, those defective bottles cannot be returned to the European suppliers for a refund, because they are not deemed defective in the sales contract as the content is still in a normal condition according to the European standard. Those defective goods are destroyed in the European warehouse at the importer's cost. Moreover, upon arrival at a warehouse in Japan, the bottles are rechecked by the contracted logistics service provider. There, every bottle is inspected thoroughly, which mostly results in the detection of more defective bottles. As the importer has already paid the ocean freight and the import duty, the financial damage is larger in this case.

In spite of this higher cost, the importer holds on to this double inspection system as he is obliged to supply wine in a perfect condition to the Japanese retailers.

We found multiple similar examples of apparently excessive quality and service focus of Japanese firms, without clear payoffs. Japanese warehouses we visited typically illustrate a focus on poka-yoke (or foolproofness) and zero-defects by double or even triple manual checking, regardless of the cost to achieve this. For the Japanese management, the maintenance of quality and service supersedes by far the profitability of the business. In Japan, service is basically regarded free of charge. Therefore, it has traditionally been difficult to charge fees to customers for flexible delivery, information provision, consultation or value adding services. Quick delivery of goods is taken for granted. Frequent and just-in-time delivery is a must, whether it is necessary or not. Since good logistical services are regarded so essential and natural, customers are not even aware that it costs money to maintain this standard. Moreover, with the rise of electronic data interchange, logistics service providers are required to increasingly invest in computer systems to provide those services. However, fierce competition in logistics business usually does not allow the firm to recover the investment cost by increasing the rates. Japanese customers mostly do not pay for the service directly but implicitly compensate for it by continuing to give business to the service provider on the basis of longer relationships. We elaborate this in the next paragraph.

\section{e. Outsourcing or networking?}

In Japan, trust is the basis of business transactions (Sako, 1992). Long-term relationships gradually lead to a tight link between the core manufacturing firm, suppliers, and logistic service providers (Helper and Sako, 1995; Dyer and Ouchi, 1993). Even if there is no capital relationship between any of the companies, often some directors are assigned from the large manufacturer to 
the small ones. On the other hand, junior staff members of suppliers and logistics service providers are seconded to the core manufacturer to take up some of the operational or research \& development functions there, according to their specialty (Nishiguchi and Brookfield, 1997). This is a symbol of a close tie and regarded as a facility to assure future business for the small firms. Such a group of firms becomes a Keiretsu (or affiliated firms) or a Kyoryoku-kai (or cooperative circle) (Hines 1996). See Figure 4. The difference between Keiretsu Logistics and Third Party Logistics is, as such, not clear in Japan. People work together as if they belong to the same firm. A third-party logistics service provider within the Keiretsu can be regarded as a member of the family but with a separate wallet. However, once the trust has been lost between the firms, the Keiretsu relationship may be dissolved at any time by the declaration of the core firm..

This system contrasts with the Western business environment, where people tend to move from one employer to another more often than in Japan. Companies tend to keep independence whether they are large or small, and the relationship between two firms is regulated by contracts. On the other hand, people in the Western region tend to maintain personal relationships with the people co-related with each other in business for long, irrespective of who their employers are.

For large enterprises, Keiretsu formation has worked very effectively to ensure quality of products and services to customers. However, Japanese firms have recently begun to realise that the cost incurred for that service assurance is hardly justified from the short-term perspective. A solution for that tends to be more outsourcing without long-term commitment (Lamming, 2000). Keeping exclusive suppliers, distributors, warehouse operators, truckers, and forwarders is becoming more and more burdensome for the core firm because the life and death of those dependent firms totally rests on the prosperity of the core company. Nissan's recent drastic measures to cut those relationships for survival are exemplary (Gosn, 2001).

As a result, Japanese companies in Europe primarily outsource logistic operations (HIDC, 2001) and they must settle for a lower level of customer service. It is a challenge for the logistics managers of manufacturers to keep balance between service and cost on the basis of an arms-length relationship with the logistics service providers.

Figure 4. The Keiretsu concept

\section{Core Company}

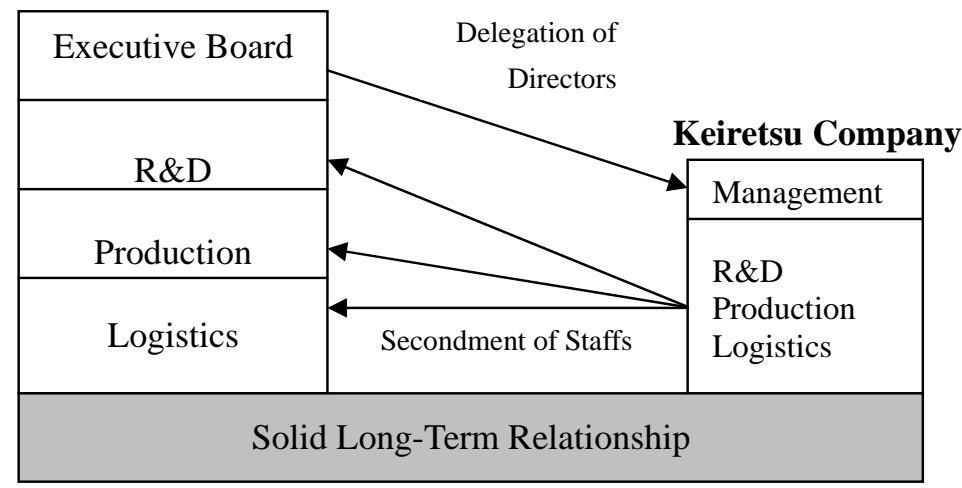




\section{Causes of differences and difficulties}

The outcomes of the interviews indeed indicate a lack in achieving performance excellence of Japanese logistics firms in Europe. The differences of concepts and practices between European and Japanese logistics illustrated in the previous section provide a general view of the difficulties that Japanese logistics face in Europe. The five problems mentioned can be related to differences in value system as expressed in Figure 2. Two key factors can be identified as follows.

\section{The unique concept of service in the Japanese system}

Good service is attached to any type of contract and taken for granted, as free of charge. Customer satisfaction is given the first priority, thus costly service provision is continued in anticipation of the reward of long-term partnership between the two firms. As such, the cost for the seemingly free service will be recovered in the long run.

Japanese customers in Europe are demanding the same level of logistics service as being provided in Japan. However, in Europe commitment of the Japanese customer to the service provider has been transformed to European standards (Taylor, 2001, found similar results in Japanese plants in China), and tends to be short-lived. For a service provider, the unique correlation between service concept and long-term mutual commitment is understandable only by Japanese managers. European managers and their staffs cannot accept cost bearing without a foreseeable opportunity for compensation. Therefore, Japanese managers are always busy visiting the existing Japanese customers in order to keep good relationship rather than trying to cultivate new non-Japanese customer bases.

\section{Distinctive characteristics of Japanese employee-relationship management}

The firms we interviewed display some features of the type- $\mathrm{Z}$ companies of Jaeger and Ouchi (1978); i.e. they have adapted themselves to Western European circumstances. However, many traditional Japanese human-resource practices are maintained for the seconded Japanese staff, such as long-term employment, generic career paths, collective responsibility, and intimate relationships between people. These elements work efficiently in networks of collaboration and knowledge creation. This system has created tacit knowledge to improve the quality of work, which is shared by all the Japanese co-workers (Nonaka \& Takeuchi, 1995).

However, in the different human resource management circumstances in Europe, several of the Japanese elements for excellence are not available. In logistics practices, rapid turnover of workers, especially of young and ambitious persons, makes it very difficult to give them a structured on-the-job training and to enhance a co-working spirit. Contracts and transparency supersede trust. Good ideas for quality improvement do not emerge from the shop floor, but top-down decision-making is the prime way to manage logistics. In contrast with manufacturing, 
in which superiority in technology plays an important role in Japanese successes (LeBlanc, 2000), logistics mainly depends on the responsiveness of human resources.

For a Japanese manager, the assignment to a job in Europe is a small part of his long career within the same company. His evaluator is in Japan. The colleagues with whom he used to work together in Japan are his valuable assets and may help him in the career path from time to time and even after retirement. In this way, there is an implicit and unconscious differentiation between overseas jobs and domestic ones. The expatriate-based management system can be characterised by an insider-outsider mentality that prevents real internationalisation of Japanese overseas operations (Legewie, 2002). European colleagues are not seen as valuable human assets like the Japanese colleagues because of the short-term relationship. The job in Europe is regarded as temporary, thus trouble-shooting becomes a main job, rather than strategic planning.

\section{How can Japanese overcome the problems in Europe?}

The recent extension of Japanese firms' supply chains to Europe has created many new problems pertaining to logistics. Obviously, the human resources available in Europe are not compatible to the Japanese business culture if no structured measures are taken to rectify the problems.

The Japanese have historically been learning from the Europeans in technologies and social management since the middle ages. When they started logistics operations in Europe, a common key word was to localise their management: “When in Rome, do what the Romans do.” Instead of introducing the typical Japanese management method with long-term employment, seniority order in promotions, on-the-job training, and beyond-contract services, short-term employment, result-oriented pay and promotion, individual job responsibility with little training in-house, and adherence to contracts were applied to the European staff of the same firm. However, top management still consists of Japanese and most of the customers of Japanese logistics service providers are still Japanese, whose requirements are no different from those given in Japan. Therefore, even if the general management tries to follow the European way, daily decision-makings and operational practices remain the same as they were in Japan.

If Japanese logistics management desires to achieve success in Europe, the above-mentioned long-established specificity of business practices should be abandoned. We suggest the following.

First, the top manager of a Japanese firm in Europe needs to be a good communicator, whether European or Japanese. He, or she, should understand both European and Japanese management styles well and be able to merge them to manage logistics in the way suitable to the supply chain specific to the firm. He, or she, will need to be able to openly exchange opinions with both European and Japanese colleagues. 
Second, staff at the head quarter at the parent company should understand the social situation and environment peculiar to the region where the subsidiary is located. Especially, the decision-making process that is inherent to Japanese management should be transformed into a generally accepted one.

Third, the head quarter of logistics service providing companies should not force the subsidiary to be adhered to the relationship with Japanese customers overseas. The growth of business abroad will depend on how many new business partnerships can be created with the firms locally operating. The top manager of the European subsidiary should be encouraged to develop a customer base out of the Japanese society. In that process, an arms-length relationship with both European and Japanese customers should be promoted.

Fourth, even in pursuing the Westernisation of management, those Japanese firms should still find their competitive edge in the traditional management method. The strength of Japanese business has been long-term thinking, excellent on-the-job training, team spirit, and knowledge transfers from the senior to the junior (Koike, 1997). Why not introduce those elements to the management in Europe? In order to do so, Japanese logisticians need to make in-depth analyses of factors that construct those practices and develop methods applicable to the European environment.

Ultimately, given the rapid globalisation of markets, there is a possibility that cultural differences in the supply chain will even bring added sophistication to the logistics management method in the future.

In this exploratory paper we gave evidence of problems in the Japanese logistical service provision in Europe, and suggested possible remedies. In follow-up researches the validity of the problems and root-causes should be assessed. We suggest a multiple-case study approach. In such research, non-Japanese companies should also be included (for example as matched pairs) in order to demonstrate the unique character of Japanese problems and future potentiality.

\section{References}

Adler, P.S., R.E. Cole (1993), Designed for learning: A tale of two auto plants, Sloan Management Review, Spring, 85-94

De Koster, M.B.M., P. Warffemius (2005), American, Asian and third party international warehouse operations in Europe: A performance comparison, International Journal of Operations and Production Management 25(8), 762-780.

Dyer, J.H., W.G. Ouchi (1993), Japanese style partnerships: Giving companies a competitive edge, MIT Sloan Management Review 35(1), Fall, 51-63.

Fahy, J., F. Taguchi (1995), Reassessing the Japanese distribution system, MIT Sloan Management Review 36(2), Winter, 49-61. 
Forza, C., R. Filippini (1998), TQM input on quality conformance and customer satisfaction: a causal model, International Journal of Production Economics 55(1), 1-20.

Gosn, C. (2001), Renaissance, Diamond Sha, Japan

Helper, S.R., M. Sako (1995), Supplier relations in Japan and the United States: Are they converging?, MIT Sloan Management Review 36(3), 77-84.

HIDC, Van EDC naar ELC, Holland International Distribution Council, Zoetermeer, 2001.

Hines, P. (1996) "Network sourcing in Japan", The International Journal of Logistics Management Vol. 7- 11, pp.13-28

The Japan Institute of Labour (1999) Dai 3-kai Kaigai haken kinmusha no shokugyo to seikatsu ni kansuru chosa kekka (The 3rd survey report on the job and the living of the workers assigned abroad), in Japanese, Tokyo, Japan

Koike, K. (1997), "Nippon kigyo no jinzai keisei (Human resource development in Japanese enterprises)" Chuko Shinsho, Japan

Lamming, R. (2000), Japanese supply chain relationships in recession, Long range planning 33(6), 757-778.

LeBlanc, L.J. (2000), The impact of information technology on operations management, International Journal of Technology Management 20(304), 243-251.

Legewie, J. (2002), Control and co-ordination of Japanese subsidiaries in China: problems of an expatriate-based management system, International Journal of Human Resource Management 13(6), 901-919.

Liker, J.K., Y. Wu (2000), Japanese automakers, US suppliers and supply-chain superiority, MIT Sloan Management Review 42(1), Fall, 81-93.

Lin, C., C.N. Madu, C.-H. Kuei, M.H. Lu (2004), The relative efficiency of quality management practices, The International Journal of Quality \& Reliability Management 21(4/5), 564-577.

Madu, C.M.,, C. Kuei, C.H. Lin (1995), A comparative analysis of quality practice in manufacturing firms in the US and Taiwan, Decision Science 26(5), 621-635.

Meredith, J. (1998), “'Building operations management theory through case and field research”, Journal of Operations Management, 16, 441-454.

Nakane, C. (1967) Tate shakai no ningen kankei, Kodansha, Japan; (Japanese Society, 1970 Weidenfeld \& Nicolson, London)

Nishiguchi, T., J. Brookfield (1997), The evolution of Japanese subcontracting, MIT Sloan Management Review 39(1), Fall, 89-101.

Nonaka, I., H. Takeuchi (1995),“The knowledge-creating company: How Japanese companies create the dynamics of innovation”, Oxford University Press 
Oe, K. (1995) Japan, the Ambiguous, and Myself: The Nobel Prize Speech and Other Lectures, Kodansha International, Japan.

Ouchi, W.G., A.M. Jaeger (1978), Type Z organization: stability in the midst of mobility, The Academy of Management Review 3, 305-314.

Powell, T.C. (1995), Total quality management as competitive advantage: a review and empirical study, Strategic Management Journal 16(1), 15-37.

Sako, M. (1992), Prices, quality, and trust: inter-firm relations in Britain and Japan, Cambridge University Press, UK.

Samson, D., M. Terziovslei (1999), The relationship between total quality management practices and operational performance, Journal of Operations Management 17(4), 393-409.

Schonberger, R.J. (1982), Japanese manufacturing techniques. Nine hidden lessons in simplicity, The Free Press, New York.

Slack, N., S. Chambers, R. Johnston (2001), Operations Management, Prentice Hall, Harlow

Taylor, B. (2001) , The management of labour in Japanese manufacturing plants in China, International Journal of Human Resource Management 12(4), 601-620.

Van Breukelen, R.H., C.B. Koolhaas, T. Kumpe (1998), The improvement machine - Results of a worldwide study of the operational performance of industrial organizations, Addison Wesley-Longman, Amsterdam.

Yeung. A.C.L., E. Cheng, L.-Y. Chan (2004), from customer orientation to customer satisfaction: the gap between theory and practice, IEEE Transactions on Engineering Management 51(1), 85.

Yukashoken Hokokusho 2003, (Annual Report 2003), Hitachi Transport, available at http://www.hitachi-hb.co.jp/ir/pdf/44th_yuho.pdf, consulted at 25 June 2004. 


\section{Appendix}

\section{Companies involved in the site visits and interviews}

Yamaha

MOL Logistics

Sony Logistics Europe

Tsubakimoto Europe

Mitsubishi Motor Netherlands

Toyota Motor France

Toyota spare parts Europe

Hitachi data systems

Fuji Photo Film Europe

IRIS Ohyama

Kintetsu World Express

Marantz Europe

Meidi-Ya Rotterdam

Mitsubishi Logistics Europe

Mitsubishi Nederland

Nichirei

Nippon Express Rotterdam

Nissin Transport Germany

NPK Europe

Ricoh Logistics

Sato Corporation

Seino Logix

Yamato Transport Netherlands 


\section{Publications in the Report Series Research* in Management}

\section{ERIM Research Program: "Business Processes, Logistics and Information Systems"}

\section{6}

Smart Business Networks Design and Business Genetics

L-F Pau

ERS-2006-002-LIS

http://hdl.handle.net/1765/7319

Designing and Evaluating Sustainable Logistics Networks J. Quariguasi Frota Neto, J.M. Bloemhof-Ruwaard, J.A.E.E. van Nunen and H.W.G.M. van Heck ERS-2006-003-LIS

http://hdl.handle.net/1765/7320

Design and Control of Warehouse Order Picking: a literature review

René de Koster, Tho Le-Duc and Kees Jan Roodbergen

ERS-2006-005-LIS

http://hdl.handle.net/1765/7322

A Theoretical Analysis of Cooperative Behavior in Multi-Agent Q-learning Ludo Waltman and Uzay Kaymak ERS-2006-006-LIS

http://hdl.handle.net/1765/7323

Supply-Chain Culture Clashes in Europe. Pitfalls in Japanese Service Operations M.B.M. de Koster and M. Shinohara

ERS-2006-007-LIS

* A complete overview of the ERIM Report Series Research in Management: https://ep.eur.nl/handle/1765/1

ERIM Research Programs:

LIS Business Processes, Logistics and Information Systems

ORG Organizing for Performance

MKT Marketing

F\&A Finance and Accounting

STR Strategy and Entrepreneurship 